\title{
DR. H. R. LILLIE
}

\section{H. M. Rayner - Ituna}

$\mathbf{U}$ NDER the caption "Natural History Museum praised," The Saskatchewan Municipal Record for March 1952 refers to the activities of Dr. H. R. Lillie of Dundee, Scotland. These activities, I think, deserve attention from all who interest themselves in the welfare of wild animals. That probably takes in every reader of The Blue Jay.

The Record describes Dr. Lillie as "a globe-trotting medical doctor who spends much of his time preaching conservation and the humane treatment of wild animals."

The question of cruelty to wild animals, and in particular to wild mammals, has been engaging the active attention of nature lovers in the United Kingdom for some time. Some two years ago last autumn, their government appointed a committee to inquire into practices and activities which may involve cruelty to British wild mammals.

The Countryman, a quarterly review of rural life and work (a publication about which I shall have more to say in a future letter) features in its autumn 1951 issue five brief commentaries on the report of this committee by five eminent authorities in the field of natural history.

There can be no doubt that much cruelty to wild animals follows from thoughtlessness, and not from deliberate intent to be cruel. Few trappers, I believe, when setting the ordinary steel trap (called a "gin" in the U.K.) give a thought to the suffering of an animal caught in one. Many who use these traps would be shocked if the realization of the suffering caused could be brought home to their consciences.

I think we should all lend support to the movement to outlaw the "gin," as it is already cutlawed (according to Dr. Lillie) in Norway, Austria, and Germany.

If death-giving traps were more in demand, manufacturers would soon improve on them to the point where it would pay trappers to use them. Other things being equal, a deathgiving trap is advantageous to the trapper. It eliminates the possibility of escape, and the captured animal will not injure its fur.

We have one pitfall to guard against. An over-sentimental approach may defeat our own end. Certain wild animals must be killed. In the United Kingdom, as well as in Australia and New Zealand, rabbi's are a serious menace to agriculture. Systematic destruction of them is almost a matter of survival.

To come nearer home, we have crows, magpies, gophers, rats and coyotes. No one, I think, will contend that it is not necessary or desirable to reduce the number of any or all of these species when by their numbers they threaten the continuance of other species, or become a menace to agriculture. I repeat, some wild animals must be killed.

Can we kill without cruelty? The whole question of cruelty to wild animals is far from a simple one. Let us take a familiar example. A magpie comes within range of your gun. Here is a chance to kill it. But even the best shots can never be quite sure of a clean kill. You may only wound the bird, with all the consequent suffering that no doubt follows. If you don't shoot, the magpie goes on his way, hunting the young ducklings along the lake shores and over the marshes. He will find and kill many of them. Nor will he be troubled with any scruples about merciful methods.

Professor J. Ritchie of Edinburg points out that while the naturalist regards wild animals as having rights of their own, the law gives man the power of life and death over them. Surely then, all wild animals, where the death penalty is involved, deserve no less than that it be carried out as mercifully as possible.

However, amending the law is not enough. Professor Ritchie goes on to remind us the prosecutions and penalties will never eradicate cruelty. A better, more fruitful approach must be kept constantly in mind, to wit, cultivation in the young of an interest in, and understanding of, wild life. To this end he pleads for more inspirational biology in the school room. 